\title{
Abraham Gross \\ Liturgy as Personal Memorial for the Victims in 1096
}

One would be hard-pressed to find a topic in recent medieval Jewish historiography that equals, in terms of abundance, scores of books and articles, ranges of treatment, numbers of scholars involved, and innovative methodologies, that of the Crusaders' persecutions of the Jews of the Rhineland during 1096. It seems that, beyond martyrdom, the denominator common to almost every aspect of historiographical coverage, is that of memory. This is so because one of the only views that has achieved consensus among scholars is that the tragic events of 1096 left their mark on the collective religious psyche of Ashkenazi Jewry. One would therefore certainly have expected a fully-fledged study analysing the memory of 1096 in the immediately following generations within the Jewish communities of Germany. Yet, despite the considerable attention that has been given to collective memory in Jewish historiography in the past three decades, such a comprehensive study on 1096 remains a desideratum. ${ }^{1}$

Recent studies have discussed the memory of 1096 mostly in connection with assessments of the extent of damage suffered during the persecutions (such as loss of lives and physical destruction), and its impact on the communities. The discussion of memory is limited to the chronological and geographical dimensions, namely, to the questions whether the persecutions were remembered in the long range (in terms of centuries), and how far away from the Rhenish 'ground zero' this memory operated? Generally, it may be said that the present trend is to minimize the losses, the repercussions of the persecutions, and the memory of the entire ordeal. ${ }^{2}$

The present study is not concerned with the memory of 1096 but with its memorialization. My interest is in what I conceive to have been the massive,

1 Among those who have treated aspects of 1096 memorialization in the twelfth century are: Simha Goldin, The Ways of Jewish Martyrdom (English translation; Turnhout: Brepols, 2008); Nati Barak, 'The Book of Memory of the Jewish Communities in Ashkenaz in the Middle Ages (Memorbuch): Its Origin, Aims, and Role in the Ceremony of Memorialization' (master's dissertation, Tel Aviv University, 2003); David Wachtel, 'The Ritual and Liturgical Commemoration of Two Medieval Persecutions' (master's dissertation, Columbia University, 1995). A short exchange between Ezra Fleischer and Yisrael Yuval concerning the Memorbuch can be found in Zion, 59 (1994), p. 294, n. 89, p. 384, n. 81.

2 The long-range memory of 1096 is briefly discussed in the introduction to a forthcoming edition of 1096 liturgical poetry by Avraham Fraenkel and myself. The present article stems from that study. 
versatile, and unprecedented effort at the memorialization that was undertaken by the generations that immediately followed 1096 in Germany. The survivors of 1096 saw themselves as the 'remnant.' Expressions such as she'erit or she'erit ha-pleța are common in post-1096 liturgy and other literary sources. Those generations constructed a system of memorialization for the events and for the victims. It was unique and unprecedented in its comprehensiveness and included a number of innovative elements.

A central question that I will try to answer, at least in part, is: Was the memorializing effort simply a product of the religious mind of Ashkenazi society or was there another motive, based on a human impulse equally wellknown to modern society? In other words, were liturgy, customs, and halakha designed as means to ends that cannot justifiably be described as 'religious', and, if so, to what degree?

I am here concerned only with liturgy, and in this context we should ask whether the sole intention of the liturgical poets [henceforth: payyetanim] was to request divine forgiveness, mercy, revenge, and redemption. If the answer is in the affirmative, then the historiographical significance is that we are limiting our understanding of their words to a basic level that defines them in exclusively religious terms. That is how liturgy is often read. After all, religious poetry is written in accordance with traditional forms, its language is by and large that of biblical and post-biblical sacred literature, and it is meant to be recited in the synagogue. There is, however, the other possibility that the intention of the entire liturgical system, or at least parts of it, was to soothe the emotional needs of a people that had lost its community, its revered rabbis, its close friends and dear relatives. To what extent can we identify in the liturgical heritage of the 1096 remnant this need for a preservation of memory that is distinct from explicitly religious language and content?

This explains why I preferred to use in the title of this article the neutral term 'victims', rather than 'martyrs', which has an exclusively religious connotation. The 'victims' (or 'dead', for that matter) need not be classified as 'martyrs', certainly not by historians, and the memorializiation of such persons may be, but need not be, restricted to the religious sphere.

The source material of this present study is the liturgy written about the events of 1096. That liturgy, dedicated wholly to 1096, numbers about thirty poems that were composed during the twelfth century. Some explicitly mention the date (תתנ"ו, תנו"ת רנ"ו, כל"ו), while others simply describe the destruction and martyrdom. There are some additional poems that mention 1096 together with later persecutions of the twelfth century, such as those of the Second Crusade (1147) and the blood libel at Blois (1171).

Liturgical poetry relating to the First Crusade may be divided into three main genres: qinot, selihot, and zulatot. The qinot were to be recited on the 
fast of the Ninth of Av, in addition to the traditional qinot on the destruction of the two Jerusalem temples. The selihot were written for days of communal commemoration of the 1096 catastrophe, as well as for the yamim nora'im, and especially for Yom Kippur. Zulatot were to be recited in the morning prayer [shaharit] of the sabbaths during the month of Iyyar, and until the festival of Shavu'ot (Pentecost), corresponding to the period of the attacks on the major Jewish communities. ${ }^{3}$

A communal hazzan [sheli'ah șibbur] was expected to write liturgy. Yet, not all the liturgical poems [henceforth: piyyuț/piyyuțim] were written by 'professional' payyețanim. For example, David bar Meshullam who wrote Elohim al domi le-dami, one of the most famous and imposing 1096 piyyutim, was a communal leader. This is the only piyyut we have by him. We may assume that he created it to satisfy his own emotional need, or that he believed that it was important for the community. We may also safely assume that anyone who wrote a 1096 piyyut, the communal payyetan included, had an agenda that guided his writing. If so, then we must treat liturgy just as historians have been treating the 1096 Hebrew chronicles, and ask two questions. How did the 1096 payyetanim perceive their communal-religious duty in the post-1096 Ashkenazi milieu? What were the results they were attempting to achieve in writing '1096 liturgy'?

A partial list of of their possible aims would have to include: to call upon God for forgiveness through the merit of the martyrs; to avenge their death; to hasten the Redemption; to evoke in the communal audience the memory of the catastrophe; to mourn the desecration of the Torah scrolls, the killing of scholars, women, and nurslings; to remind the audience what the Christians did and thus broaden the gap between the two faiths; to contribute to internal social cohesion; to impart an implicit message of religious loyalty unto death as exemplified by the martyrs; to strengthen faith in the ongoing covenant between God and Israel; to justify divine judgement; to raise feelings of pride in belonging to the chosen people; to 'prove' the veracity of Judaism out of the readiness of the martyrs to die for their faith; to preserve the memory of the persecutions; to lend meaning to current suffering by linking it with the ancient chain of martyrological tradition from the times of Rabbi Akiva, Rabbi Hanina ben Teradion and their colleagues; and to equate the status and reward of the martyrs in the present with those of their ancient predecessors.

At times, depending on the piyyut's specific genre and its conventional aims, the payyetan may say why he is writing. But not everything is by any

3 On the strictures associated with mourning customs during the month of Iyyar, specific to Ashkenazi Jewry, and their relation to 1096, see: Daniel Sperber, Jewish Customs: Origins and History (Hebrew; Jerusalem: Mosad Harav Kook, 1989), pp. 110-11. 
means explicit. It seems that all too often, central aims remain implicit. As one examines the payyețan's intentions, one thing becomes apparent. He does not detail the religious and social agenda that he is trying to impart to the audience. By 'implicit' intentions, I refer not only to intentionally hidden messages, but also to those that play a role in the creative process of the composition without the conscious consideration of them by the payyetan.

Now that we have a tentative list of aims, we must ask, of course, how important the element of memorialization is within this framework. A detailed answer to the question is beyond the limited scope of the present article. In general, however, I would suggest the following:

a. the answer might vary from piyyut to piyyut, from payyețan to payyetan, and from generation to generation.

b. analysis of the entire poetical corpus appears to me to suggest that the element is more central than most historians have acknowledged to date.

Let us take, for example, Qalonymos bar Yehuda. Qalonymos, a member of the community of Mainz, wrote at least five (!) 1096 liturgical poems. He may certainly be given the honorary title of the foremost 1096 payyetan. The time of composition is estimated to be between ten and twenty years after the events.

Now, why would one write five piyyutim (two qinot for the Ninth of Av, and three selihot) ${ }^{4}$ Why does he relate the self-slaughter in one qina while completely ignoring it in the other? Why does he transcribe in one qina the names of the major communities and the dates on which they were attacked? It would seem that Qalonymos intended to produce a series of piyyutim designed to complement each other and to create one whole poetic narrative. This narrative's aim was, primarily, to serve as a poetical memorial to the destroyed communities. One might say that, in this respect, he was attempting a poetical parallel to the Hebrew prose accounts of 1096.

A comprehensive assessment of 1096 liturgy as a collective memorial requires an independent study. I would like to present here only one side of the issue, namely, the phenomenon of personal memorialization in that liturgy. In this instance, I will refer mainly (but not exclusively) to Qalonymos bar Yehuda's piyyuțim.

One of the most discussed martyrological episodes related in the 1096 Hebrew chronicles is that of Rachel of Mainz, who slaughtered her children in order to prevent their baptism. The story is extant in two versions. It seems

4 It is unlikely that he wrote any seliha for the memorial day observed by the Mainz community because he seems to advocate in one qina (mi yiten roshi mayyim) a collective mourning for all the communities on the Ninth of Av. 
that Qalonymos bar Yehuda refers to it in his Amarti she'u. In this qina he describes scenes of self-slaughter in Mainz and uses expressions and lines that appear in the long version of the Rachel narrative in Shelomo bar Shimshon's chronicle [henceforth: Chronicle A]. Isaiah Sonne concluded from his detailed literary analysis that in this instance Chronicle A is based on the version of the chronicle of the Mainz Anonymous [henceforth: Chronicle C] and the author embellished it with lines from Qalonymos's piyyuț. Yitzhak Baer, on the other hand, insisted that Qalonymos based his piyyut on Chronicle A's version. In fact, both positions are untenable. Elsewhere, I have suggested a tentative solution for this literary problem. ${ }^{5}$ Be that as it may, one thing is beyond controversy: Qalonymos was aware of, and refers in his qina to the Rachel story. Let us look at the relevant lines:

The beautiful one who dwells within,

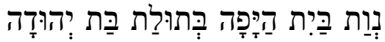

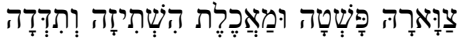

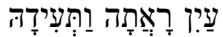

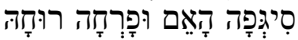

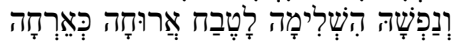

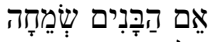

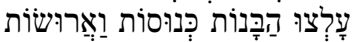

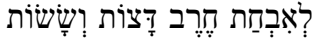

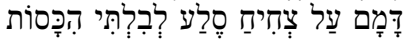

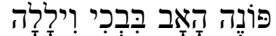

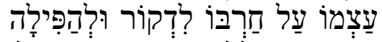

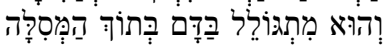

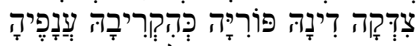

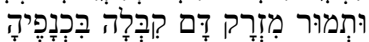

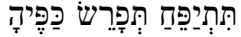

the maiden daughter of Judah,

stretched her neck and honed and sharpened her knife;

An eye saw and testified.

Tormented was the mother and her spirit flew away

she submitted her soul to the slaughter

as if she was preparing a meal.

The mother of children rejoices.

The daughters exulted, those wed and those betrothed,

they rushed joyfully and gladly to the scourging sword,

their blood [shed] on a smooth rock, never to be covered over.

The father turns away with weeping and wailing,

throwing himself on the sword to be stabbed.

5 Abraham Gross, 'Historical and Halakhic Aspects of the Mass Martyrdom in Mainz: An Integrative Approach', in Facing the Cross; The Persecutions of 1096 in History and Historiography, ed. by Y. Assis et al. (Hebrew; Jerusalem: Magnes Press, 2000), pp. 187-91. 
He wallows in his own blood on the street.

The fruitful [mother] proclaimed the righteousness of her judgement as she offered her scions.

And instead of the consecrated basin she caught [the blood] in the hem of her garment, sobbing and spreading out her arms. ${ }^{6}$

Now the payyețan did not reveal any specifics. He did not provide personal names. He did not even mention the name of the community in this particular piyyut. In following such a policy, he uprooted, so to speak, the story from its original personal domain and endowed it with a collective dimension. Moreover, since the anonymity of the martyrs and of the community was maintained, all readers, even those who did not have a direct personal or communal connection to the events, including Jewish mourners in generations to come, would be able to identify with the non-personal, collective martyrdom described by Qalonymos. But the basic dimension of the piyyut is communal. His Mainz audience knew intimately the historical background of this piyyut. Clearly, there were others in Mainz who had experienced, had seen, or had heard of, similar events and could identify parts of the piyyut with specific episodes or persons within the collective catastrophe.

If my analysis of the payyetan's intentions is so far accepted, another question occurs. True, he wished to compose a poetic account of the 'epic' dimensions of the martyrdom. But did he intend to reveal, or at least hint, to his contemporary audience about Rachel's personal martyrdom? The composition of this influential piyyut and the beginning of its communal use in the Mainz synagogue service apparently date to no later than the two decades after 1096. Therefore, we may assume that some of the Mainz elders who survived the persecutions were still alive. This being the case, it is highly improbable that they had neither heard nor read of the incident.

It is fashionable to set the Rachel story, in the long version of Chronicle $\mathrm{A}$, in the context of Jewish-Christian polemics and interpret it as a literary attempt to construct a typological image of a superior Jewish woman-martyr. This line of historiography notwithstanding, one fact should be stated clearly: Rachel was not an imaginary figure. She was a woman of flesh and blood. She and her children are mentioned in the Memorbuch among the martyrs of 1096 in Mainz. Moreover, both accounts state that she was the 'daughter of Rabbi Yiṣhaq bar Asher’. Mentioning two generations of her genealogy is not a com-

6 The translation of this piyyut is based mainly on earlier translations by Abraham Rosenfeld, Kinot for the Ninth of $A v$ (London: Labworth, 1965), and Avrohom C. Feuer and Avie Gold, The Complete Tishah B'av Service (ArtScroll Mesorah Series), (New York: Mesorah Publications, 1991). 
mon characteristic. It is plausible that the reason for it is that Rabbi Yiṣhaq bar Asher was none other than one of the foremost scholars of that generation. ${ }^{7}$ If this is the case, then we may say that it is highly probable that Qalonymos indeed chose to relate the collective communal martyrdom through virtual citations of entire lines from the Rachel prose narrative as a memorial to the exceptional daughter of a revered rabbinic leader.

It seems to me that we may similarly interpret yet another section of the same piyyut. Following the Rachel lines, Qalonymos raises, in a very novel poetic manner, a theological discussion of the problem of burial of the corpses:

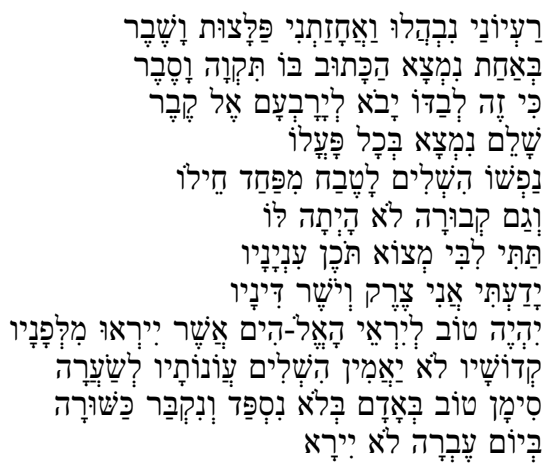

My thoughts are confounded shuddering and distraughtness take hold of me, because of one single [good deed] found in him Scriptures gives hope and expectation, for he alone of Jeroboam's [stock] shall come to the grave.

[Yet] one found perfect in his every deed, submitted himself to the slaughter in awe of God, for him there was not even a proper burial! I have set my mind to find the reason for His dealings, For this I do know: His judgements are righteous and just, and it will be good for the God-fearing that they may be awed in His Presence. He puts no trust in His holy ones, rather He punishes their sins even to a hair. Indeed it is a good sign for a man if he is not eulogized or buried properly. [Such a man] should not fear on the day of reckoning.

We have here the poetic discussion of what seems like a divine injustice in that the Jewish corpses were thrown into the streets (temporarily) in a further act of humiliation. An extreme sensitivity to the need for proper, immediate burial is also highly conspicuous throughout the 1096 Hebrew Chronicles. While we might expect a general discussion in broad terms, Qalonymos surprisingly uses the third person singular form:

7 This identification has recently been suggested by Mataniah Y. Ben-Gedalyah, 'The Sages of Speyer During and After the Persecutions of 1096: Their Biographies, Communal Leadership, and Spiritual Works' (doctoral dissertation, Bar-Ilan University, Ramat Gan, 2007), p. 64. 


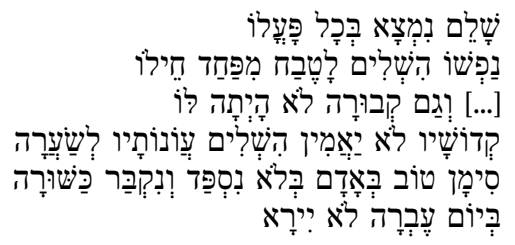

I think it may well be that the payyetan is here hinting at the death of the revered communal leader, Rabbi Qalonymos the Parnas, probably his relative. The circumstances surrounding his death were recorded in several oral traditions. According to all of these traditions, he died in, or close to, Rüdesheim, not in Mainz. In Chronicle A, where the accounts of his death are recounted, it is not clear that his corpse was ever brought to Mainz for burial, in contradistinction to other martyrs who eventually received proper burial. ${ }^{8}$ In this way, then, Qalonymos found a way to mention, mourn, and memorialize a revered communal leader.

From all of this, it follows that it is possible to ascribe to some of 1096 poets the writing of lines that were understood by all readers as general descriptions but also contained hints of an individual and personal nature.

Indeed, the mode of interpretation here offered, which presupposes an allusion to a specific woman, when the lines themselves seem to betray no such intention, is not unique. Al domi le-dami, one of the first of the 1096 piyyutim, was written by Rabbi David bar Meshullam. The context is the cruel massacre of Jewish women by the Crusaders:

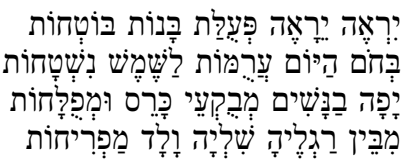

Let this sight come before You: young women who put their trust in You were stripped naked in broad daylight;

the fairest of women - their wombs slashed open

letting out the unborn from between their legs. ${ }^{9}$

To whom did that 'fairest of women' refer? Prima facie, the payyetan describes all young women, some of whom were pregnant and who were brutally murdered. The fact that the poem moves from the plural to the singular form, and then alternates between these two forms, with no apparent reason, is puzzling.

8 Concerning other members of his group, it is related that they intended to return to Mainz in order at least to be buried in a Jewish cemetery, but were killed on the way.

9 This translation is based on T. Carmi, The Penguin Book of Hebrew Verse (New York: Penguin Books, 1981), p. 375. 
The commentary on these lines in one manuscript, citing oral tradition, states: 'And I have heard that this maiden was the daughter-in-law of Rabbi Meir bar Yiṣhaq Shaș’10 Rabbi Meir bar Yiṣhaq was a much revered payyețan and scholar in the second half of the eleventh century, and therefore it stands to reason that David bar Meshullam would think of memorializing the Rabbi's daughter-in-law. ${ }^{11}$ Obviously, this tradition, with a precise identification of the woman, does not stem from the syntactic problem. There is, however, a hint that ties that beautiful, pregnant woman with Rabbi Meir bar Yișhaq Shaș. The poetic expression yir'e yera'e, which opens the verse above, is special and had been coined by Rabbi Meir himself in his 'aqeda poetry. Thus, the payyetan, while formulating his description in a generalized way, planted a clue that many of his audience would have understood, thereby making a connection to individuals. ${ }^{12}$

Rabbi Eli'ezer bar Nathan was one of the important scholars in post-1096 Mainz (died about 1153). He composed two piyyuțim about the 1096 persecution and alludes to them in two others. He also compiled one of the 1096 Chronicles. This literary work differs from the other Chronicles in that the author inserted short qinot about the major communities. After a short description of the limited killing in Speyer, a short qina is inserted. Beyond some general praise of the community the qina is, in effect, a summary of the prose description that precedes it. It includes the following factual lines:

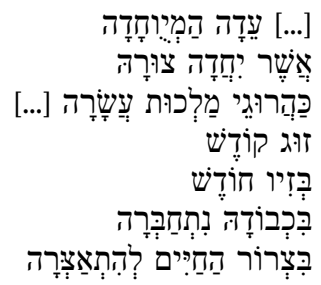

the special community

which unified its Rock

just like the Ten Martyrs [...]

Holy [Sanctified] wife

In the month of Ziv (Iyyar)

10 - Ms. Bodley 1209, fol. 84b. It is referred to in Abraham Grossman, 'The Roots of Kiddush Ha-Shem in Ancient Ashkenaz', in Sanctity of Life and Martyrdom, ed. by I. Gafni and A. Ravitzky (Hebrew; Jerusalem: Shazar Center, 1992), p. 103 n. 9.

11 Avraham Grossman, The Early Sages of Ashkenaz. Their Lives, Leadership and Works (9001096), (Hebrew; Jerusalem: Magnes Press, 1988), pp. 292-96.

12 I owe this insight to Avraham Fraenkel. 
Attached herself to her honour

To be bound in the Bond of Life

In both, the prose narrative and the piyyut, the number of people who were killed, is ten. While the piyyut likens the martyrs to the famous 'Ten Martyrs' of antiquity, the chronicle specifies that it is also the actual number of martyrs in Speyer. Those men are followed by one woman who committed suicide. She is not included in the initial ten, all of whom are men, and therefore this does not contradict Chronicles $\mathrm{A}$ and $\mathrm{C}$ which talk about eleven having been killed.

Now zug is a short form of bat-zug, 'wife', 'spouse'. So, who is the woman? Whose wife was she? According to one source, her name was Sarah, wife of Rabbi Shabbetai bar Qalonymos, the Gabbai, one of the ten martyred men. ${ }^{13}$ If this is correct - and we have no good reason to doubt it - then the payyetan hinted at the identity of the woman by calling her zug. This is a good clue in the case of this particular suicide - not to be confused with the common 1096 self-slaughter - since the source mentioned above says that she killed herself in an extreme act of grief when she heard of her husband's death. The word $z u g$ is very precisely and appropriately chosen. ${ }^{14}$

One of the piyyutim that was interpreted as referring in some of its lines to historical details and figures is berit keruta. This seliha was composed by Binyamin bar Hiyya. This payyețan is otherwise unknown but was clearly a talmudic scholar. Two of his lines read thus:

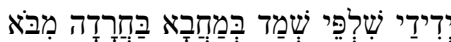

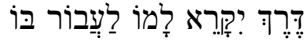

How are we to understand, let alone translate, these two difficult lines? The only general conclusion one can reach is that they are somehow related to persecution and concealment. An early thirteenth-century commentary, preserving an otherwise unknown tradition, interprets it as referring to the author himself:

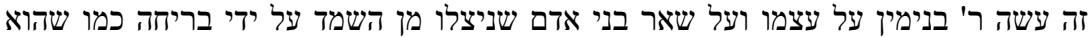

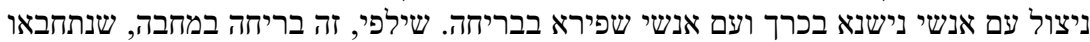
בכרך ובשאר המקומות שיכלו בכרך ועמי להנצי שני

13 For the citation of this relatively unused source, a discussion of its authenticity, and an interpretation of the poetic lines, see Ben-Gedalyah [above, n. 7], pp. 166-78.

14 This would also indicate that 'her honour' refers to her husband (although a reference to God cannot be ruled out). 
This was written by Rabbi Binyamin about himself and about others who had been saved from the persecution by escaping, just as he had been saved along with the people of Neuss in the city and with the people of Speyer through such an escape. Shilpei means escaping into hiding, since they hid in the city and in any other place where they could thus be saved.

The information as it here appears cannot be entirely accurate. ${ }^{15}$ Inaccuracy occurs all too often in the process of transmitting facts over more than a century. It should not, however, lead us to discount the general historical information imbedded in these lines according to that tradition. People were aware of the payyetan's intentions, either through knowledge of his personal ordeal during the persecutions, or through information that he himself passed on to his own community or circle. In any event, the nature of this description is personal and 'informative'. It may seem strange to find it in a seliha, the addressee of which is God. Why the need to tell Him this detail? This piyyut has other historical references, all of which make sense only in the context of a poetic narrative for which the undercurrent element of memorialization is central.

It seems to me that the interpretations given by the commentators of the twelfth and thirteenth centuries reflect, by and large, credible traditions that date back to the composition of the piyyutim. Moreover, the payyetanim themselves could have been the initial oral decipherers of the clues to individuals. Chronologically, we are on the threshold of the Hasidei Ashkenaz movement with its rigorous interpretation of every word and nuance in the prayer-book, including piyyutim. Like many elements that characterize this movement, how-

15 Chronicle $\mathrm{C}$ tell us that the Speyer community had been led away and hidden by its Bishop, in his 'fortified towns' until the Crusaders gave up and continued their journey on from there. This should not be connected in any way with the hideaway at Neuss, which was one of the towns of the Bishop of Cologne. Indeed, it was one the seven places where that Bishop hid his Jews. Chronicles A and B tell us about those who were not saved and died as martyrs and - as is all too often true about 1096 - we lack serious information about the events in Neuss. Our payyețan may have belonged to the group that had been sent from Cologne by the Bishop to hide in Neuss. The Memorbuch does record a martyr from Cologne by the name of Mar Moshe bar Hiiyya (Siegmund Salfeld, Das Martyrologium des Nürenberger Memorbuches, Berlin: Leonhard Simion, 1898, p. 9). On the other hand, there may be an indication of a local Jewish presence in Neuss prior to 1096 in Chronicles A and B, where there is the story of a martyr whose son was hanged with his sons on the door of 'his house' (Eva Haverkamp, Hebräische Berichte über die Judenverfolgungen während des Ersten Kreuzzugs, Hannover: Hahnsche Buchhandlung, 2005, p. 409). Otherwise there is no indication of a pre-1096 Jewish community in Neuss (See: Alfred Haverkamp, Geschichte der Juden im Mittelalter von der Nordsee bis zu den Südalpen, Teil 2 Ortskatalog, Hannover: Hahnsche Buchhandlung, 2002, p. 253). I thank Professor Andreas Lehnardt for this reference. 
ever, the centrality of the piyyut and close attention to its nuances date back to the eleventh century.

Admittedly, some of those oral interpretations were not intended by the payyetan. The following seems to be a case in point. Efrayim bar Yiṣhaq of Regensburg (mid-twelfth century) includes in a seliha (ani ani ha-medabber) a description of the persecutions of 1096, although the reference to them is not explicit. One lines reads as follows:

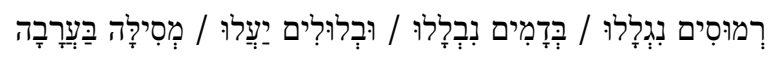

This describes trampled bodies as if they were dung, their blood mixing together, and the joint ascent of their souls to Heaven. In a thirteenth-century commentary we do, however, find:

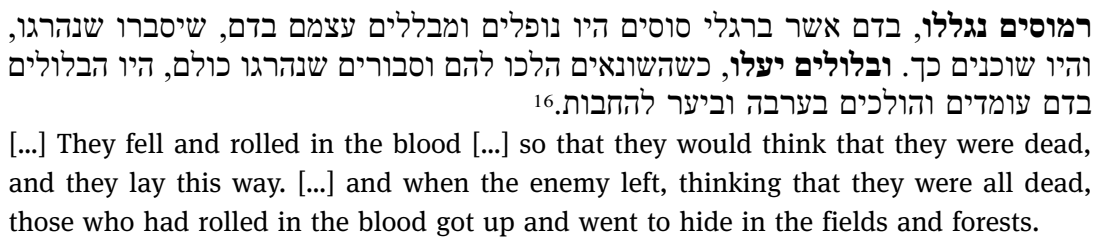

[...] They fell and rolled in the blood [...] so that they would think that they were dead, and they lay this way. [...] and when the enemy left, thinking that they were all dead, those who had rolled in the blood got up and went to hide in the fields and forests.

There is no intrinsic problem with the line of poetic text that should force us to look there for this far-fetched interpretation. It is simply eisegesis. The commentator found a line into which he could read the historical information that Ashkenazi tradition had transmitted to his generation. Here, then, we have evidence of the serious nature of public interest in the piyyutim and its expectation of finding within it a hidden store of information about 1096 that was neither religiously significant nor of any relevance to the piyyut as liturgy. ${ }^{17}$

I have posed a question concerning the weight of memory and memorialization intended by the payyetanim in composing 1096 liturgical poetry. While acknowledging the difficulty of answering this question in all its complexity, let alone in a short paper, I have attempted to establish a basic working assumption that has far-reaching implications for our understanding of the Ashkenazi medieval individual and society.

The sheer volume of the liturgical corpus should already be appreciated as an initial indication that their basic emotions and response to the masskilling and the loss of family and friends, alongside the destruction of a pros-

16 Efraim E. Urbach, Arugat Ha-Bosem, vol. 3 (Jerusalem: Mekize Nirdamim, 1963), p. 368, n. 70. 17 Compare Urbach, Arugat Ha-Bosem, vol. 4, pp. 182-84. 
perous and proud community, are rooted in the human condition. In this sense, I contend, the needs of medieval man are not much different from our own. ${ }^{18}$

We can find in the liturgical poetry more than a few references to historical details surrounding the events of 1096. Those include the recording of dates, names of communities, allusions to the Pope and his declaration of the Crusade at Clairmont, the developing stages of the Crusade, and Count Emicho. Some of the facts mentioned may be understood in religious terms as addressing either God or the community, such as I have listed above. Some data may, however, also be explained - and perhaps even primarily explained - as arising out of a need to memorialize the events separately from any practical, religious context.

Singling out, as I have done above, references to well-known martyred individuals, identifiable to the community of survivors, supplies us with unequivocal proof of my claim for an areligious memorialization, and leads to the unavoidable conclusion that they had a need to memorialize as much as possible, no matter what the literary genre. It was not only for the sake of perpetuating the memory of martyrdom, of fighting an existing trend towards apostasy, of setting up a model response for their own and for future generations, or of defining Jewish-Christian relations. Taking a religious literary medium and using it to memorialize individuals can emerge only from an emotional need that is identical to our own, that is, a desire to preserve the memory of people dear to us. Appreciating how this was achieved in a covert fashion teaches us not only the art and subtlety of the payyetanim but also the difficulty of including such personal material, which was immaterial, indeed alien, to the religious aims of piyyut. In this respect, then, 1096 liturgical poetry tries to do in a constrained fashion - given the narrowness of the religious-literary medium - what the 1096 chroniclers could do freely. ${ }^{19}$

What still await analysis and characterization are the diverse expressions of response to the events of 1096. It seems to me that every type of response,

18 For a most valuable illustration of emotions of grief expressed by a father during the Black Death, see Ron Barkai, 'On Children's Death in the Black Death', in Women, The Aged, and Children: Festschrift in Honor of Shulamit Shahar, ed. by Y. Hen and Miri Eliav-Feldon (Hebrew; Jerusalem: Shazar Center, 2001), pp. 67-84.

19 An exception to the rule is the (relatively late) adabra be-șar ruhi which describes the martyrdom at Mainz and mentions two public figures who are also named in the Chronicles. From the second half of the twelfth century, we encounter the explicit naming of martyrs. This applies to cases of persecutions on a smaller scale than 1096, such as the blood libel and the host libel. One should also take into account that the very writing of piyyutim (especially of qinot) on local persecutions is in itself a daring novelty, and the mentioning of names should be seen as a further stage in the development of this genre. 
be it literary or behavioural, has its parallel in contemporary modes of memorialization, especially of the victims of terror and those who have fallen in the military. The differences are cultural. Thus, secular society, devoid of religious beliefs in, or concern with, the afterlife, the eternity of the soul, reward and punishment and related matters, cannot memorialize the dead within the system of beliefs and the language of generations past. Hence, contemporary modes of memorialization have come into being. Modern culture has adapted itself but has not invented anything new, save for technological innovations that enable new formats of memorialization. These modern means hardly change the essence of things. Twelfth-century Ashkenazi society needed, and therefore developed, a variety of vehicles of memorialization. These included, among others, general customs to strengthen the folk memory, the rituals of memorial days, and the compilation of a Memorbuch, that is, a list of the names of the victims to be read in the synagogue on certain occasions.

Although the Memorbuch is not the focus of the present article, a short comment on its nature will illustrate the point I am trying to make concerning 1096 liturgy. According to Yisrael Yuval, the Memorbuch testifies to 'the deep penetration of the revenge concept into the religious ritual of Ashkenazi Jews in the Middle Ages'. This assessment was rejected by Ezra Fleischer who preferred to see in it a testimony to their simple wish to remember their dead martyrs on certain dates. Yuval's reply was: 'Emotionally, this is certainly true. Nevertheless, the ritual significance of hazkarat neshamot [and not zekhirat neshamot] in the Memorbuch does not relate to the memory of man but to that of God [yizkor Elohim] [...].' ${ }^{20}$ Yuval was saying that, if Fleischer was right, then the ritual of memory of the dead should have been called zekhirat (= 'remembering', or, 'mentioning') and not hazkarat [= 'reminding'] neshamot. Reminding can be directed only to God, and, according to Yuval, this is for the purpose of avenging the death of the victims.

If we adhere closely to the written word, Yuval is certainly right. After all, it is a double-edged prayer to God, requesting Him to remember the victims and to avenge their death. Since, however, there is a wide recognition of the presence of an emotional dimension beyond the religious one, we need to pose a number of questions. How important is the emotional element in the Yizkor prayer? Is it central, or secondary to the ritual? Why, according to Fleischer, is this dimension absent from the words of the prayer? The answer to the last question is, in my opinion, fairly simple - because it is a prayer, and not a modern civic memorial service whose explicit focus is the expression of collective grief and pain.

20 See above n. 1. 
Yet, the medieval ritual is no different from the hazkarat neshamot, still practised today, 900 years after 1096. A strong expression of human and personal emotions is present, even if the language and contents are religious. In other words, we encounter here a ritualization of emotions. The expression of emotions passes through a religious vortex, so to speak, and the result is a ritualistic expression. What we therefore meet here is a traditional outer shell of language that hides within itself human impulses and emotions. These are destined to receive their direct, personal, and unmediated expressions, as we know them, only in the modern-secular era.

This seems to hold true for the piyyutim, the main topic of the present article. The language they knew best was religious. ${ }^{21}$ And so, liturgy had to be the choice, and in accordance with the forms dictated by synagogal tradition. However, the impulse beneath this religious surface was one of grief, loss, and longing. I suggest that we should view the Memorbuch in the same vein. I believe that this is the correct approach to the entire issue of the medieval Jewish memorialization of victims that is concealed in all genres of post-persecution literature. 22

21 Cf. Lucette Valenci, 'From Sacred History to Historical Memory and Back: The Jewish Past', History and Anthropology 2 (1986), pp. 283-91. I thank Amnon Raz-Krakotzkin for bringing this article to my attention.

22 Elsewhere, I have suggested that memorialization is a crucial motivating factor in the composition of the Hebrew Chronicles of 1096 (Abraham Gross, 'Reflections on Halakhic and Non-Halakhic Aspects of Kiddush Ha-Shem in 1096', in Be'erot Yitzhak: Studies in Memory of Isadore Twersky, ed. by Jay M. Harris (Cambridge MA: Harvard University Press, 2005), pp. 24-25). 
